\title{
Nitrogen Rate and Cutting Management for Fenugreek Green Leaf and Seed Production
}

\author{
Satybhan Singh ${ }^{1,3}$, V. K. Dhangrah ${ }^{1 *}$, Virendra Singh ${ }^{1}$, O. V. S. Thenua ${ }^{2}$, Krishan Pal ${ }^{1}$ and R. D. Shukla ${ }^{1}$ \\ ${ }^{1}$ School of Agricultural Sciences \& Engineering, IFTM University, Moradabad, U.P. (244 102), India \\ ${ }^{2}$ Dept. of Agronomy, Amar Singh (P.G.) College, Lakhaoti, Bulandshahr, U.P. (203 407), India \\ ${ }^{3}$ Dept. of Agronomy, Aroma College Roorkee, Haridwar, Uttarakhand (249 405), India
}

\section{Corresponding Author}

V. K. Dhangrah

e-mail:vinod.dhangrah@gmail.com

\author{
Article History \\ Article ID: AR1892 \\ Received in $07^{\text {th }}$ August, 2018 \\ Received in revised form $25^{\text {th }}$ August, 2018 \\ Accepted in final form $27^{\text {th }}$ August, 2018
}

\begin{abstract}
Fenugreek (Trigonella foenum-graecum L.) is an annual seed spice crop also used as a leafy vegetable, and reported to have medicinal properties. Farmers usually practice leaf cutting in fenugreek only when crop grown for vegetable purpose. There is need to standardize the nitrogen requirement when leaf cutting is practiced at different stages of growth since it may influence leaf and seed yields. Hence, present field Experiment was conducted to study the effect of Nitrogen rate and Cutting Management on Fenugreek leaf and seed production during $15^{\text {th }}$ November, 2015 to $25^{\text {th }}$ March, 2016. Treatments were comprised of three nitrogen levels of 20,40 or $60 \mathrm{~kg}^{-1}$ and three levels of cutting i.e. no cutting, or cutting at 45 or 60 days after sowing (DAS). All treatment combinations were replicated 3 times in a factorial randomized complete block design. The observations were recorded on plant height, number of pods plant ${ }^{-1}$, number of seed $\operatorname{pod}^{-1}$, green leaf yield, seed yield and biological yield (sum of seed and straw yield). Harvest index was calculated by dividing economic yield to biological yield. The results revealed that increased green leaf and seed yields occurred when nitrogen level increased and cutting was delayed. The maximum harvest index (0.44) was when nitrogen was applied @ $60 \mathrm{~kg} \mathrm{ha}^{-1}$ and plants were cut at 60 DAS. Thus, delaying cutting increases nitrogen requirement in fenugreek if supplied in proper amount, it results to increased yield.
\end{abstract}

Keywords: Fenugreek, nitrogen rate, cutting management, leaf, seed production

\section{Introduction}

Fenugreek (Trigonella foenum-graecum L.), commonly known as methi is an annual herbaceous plant belonging to family Fabaceae. Its seeds are used as spice in the preparation of pickles, vegetable dishes, dal, and spice mixes such as panch phoron and sambar powder. Fresh fenugreek leaves are an ingredient in some curries, such as "aloo methi" curry. It has also been reported to have medicinal properties (Syeda et al., 2008; Vidyashankar, 2016). India is a major producer, with fenugreek production in India derived from numerous states. Rajasthan accounts for over $80 \%$ of India's output (Parthasarathy et al., 2008). Being a leguminous vegetable, it fixes atmospheric nitrogen in the soil which helps in improving soil fertility. Nitrogen is essential for vegetative growth of the plant resulting in higher green and seed yield (Tehelan and Thakral, 2008; Tunctruk et al., 2011). Increased addition of nitrogen usually results in increased yield of crop plant (Korus and Lisiewska, 2009). Productivity of the crop is low but may be increased with supply of optimum amounts of fertilizer and improved agronomic practices. Apical bud pinching helps in altering the source sink relationship by curbing the vegetative growth and hastening reproductive phase of the plant. It also helps in production of side shoots or branches thus resulting in increased photosynthetic activity and accumulation of more photo-synthates ultimately resulting in increased seed size and yield (Lakshmi et al., 2015). Cutting of stems significantly effects branching and enhances flowering in most of the crops (Ahmed and Oladiaran, 2012). Since in most of the leafy vegetables several cuttings are possible, they require a good amount of fertilizer for quick growth. One or 2 leaf cutting may be done if adequate nitrogen is supplied since it is associated with vigorous vegetative growth, leading to higher seed production. The experiment was undertaken to determine the best nitrogen level and appropriate stage of leaf cutting to enhance yield.

\section{Materials and Methods}

The present field Experiment was conducted during $15^{\text {th }}$ November, 2015 to $25^{\text {th }}$ March, 2016 to study the effect of Nitrogen rate and Cutting Management on Fenugreek leaf and seed production. The experiment took place at the 
Agriculture Farm of Aroma College, Roorkee (Uttarakhand), India. The experimental site lies between $29.52^{\circ} \mathrm{N}$ Latitude and $78.53^{\circ} \mathrm{E}$ Longitude at $270 \mathrm{~m}$ above the mean sea level. The soil was a sandy loam with homogenous fertility and good drainage. The experiment included the nitrogen levels of 20,40 or $60 \mathrm{~kg} \mathrm{ha}^{-1}$ and cutting treatments of no cutting, and cutting at 45 or 60 days after sowing. Phosphorus and potassium were applied at the rate of 40 and $20 \mathrm{~kg} \mathrm{ha}^{-1}$, respectively. All treatment combinations were replicated 3 times in a factorial randomized complete block design. Seeds of cv. Pusa Early Bunching were sown on $15^{\text {th }}$ November of 2015 at a rate of $25 \mathrm{~kg} \mathrm{ha}^{-1}$ in row to row spacing of $30 \mathrm{~cm}$. The crop was thinned out 25 days after sowing to provide a plant to plant distance of $10 \mathrm{~cm}$. In respect of treatments, first time leaf cutting was done on $30^{\text {th }}$ December of 2015 and the second time on $15^{\text {th }}$ January of 2016. The crop was harvested for seed yield on $25^{\text {th }}$ March of 2016. The crop was irrigated in flood at 10 days interval by the end of January month and further at 7 days interval 15 March 2016. Pesticides i.e. carbendazim 50\% WP @ $2 \mathrm{ml} \mathrm{l}^{-1}$ and imidacloprid 17.8\% SL
@ $1.5 \mathrm{ml} \mathrm{l}^{-1}$ were applied twice after each cutting to keep the crop free of fungal disease and insects, respectively.

Measurements of plant height, number of branches plant ${ }^{-1}$, number of pods plant ${ }^{-1}$, number of seed pod ${ }^{-1}$, test weight (1000 seed weight), seed yield, biological yield and green leaf yield were obtained. Harvest index was calculated by the formula of Donald (1962). Data were analyzed statistically following Gomez and Gomez (1983). If the interaction was significant it was used to explain the results and the difference between treatments was compared with LSD.

\section{Results and Discussion}

Analysis of variance showed that all growth and yield parameters were affected by nitrogen dose except for number of branches plant ${ }^{-1}$ and harvest index (Table 1). Plant height, number of pods plant ${ }^{-1}$, number of seed pod ${ }^{-1}$, test weight, seed yield, green leaf yield and biological yield increased with increasing nitrogen level (Table 2). Plant height has positive correlation with green leaf yield as well as seed yield (Singh

\begin{tabular}{lcccccccccc}
\hline \multicolumn{1}{l}{ Table 1: Analysis of variance for fenugreek characters due to effect of nitrogen levels and cutting stages } \\
\hline Source & d.f. & $\begin{array}{c}\text { Plant } \\
\text { height } \\
\text { (cm) }\end{array}$ & $\begin{array}{c}\text { No. of } \\
\text { branches } \\
\text { plant }^{-1}\end{array}$ & $\begin{array}{c}\text { No. of } \\
\text { pod- } \\
\text { splant }\end{array}$ & $\begin{array}{c}\text { No. of } \\
\text { seeds } \\
\text { pod }^{-1}\end{array}$ & $\begin{array}{c}\text { Test } \\
\text { weight } \\
(\mathrm{g})\end{array}$ & $\begin{array}{c}\text { Seed } \\
\text { yield } \\
\left(\mathrm{mt} \mathrm{ha}^{-1}\right)\end{array}$ & $\begin{array}{c}\text { Green } \\
\text { leaf yield } \\
\left(\mathrm{mt} \mathrm{ha}^{-1}\right)\end{array}$ & $\begin{array}{c}\text { Biological } \\
\text { yield } \\
\left(\mathrm{mt} \mathrm{ha}^{-1}\right)\end{array}$ & $\begin{array}{c}\text { Harvest } \\
\text { index }\end{array}$ \\
\hline Nitrogen (N) & 2 & $1275.80^{* *}$ & 1.27 & $92.96^{* *}$ & $6.05^{*}$ & $2.03^{*}$ & $0.136^{* *}$ & $0.006^{*}$ & $1.378^{* *}$ & 0.005 \\
Cutting (C) & 2 & $1873.61^{* *}$ & $8.71^{* *}$ & $689.39^{* *}$ & $7.43^{* *}$ & $2.67^{*}$ & $0.266^{* *}$ & $0.863^{* *}$ & 0.137 & $0.017^{* *}$ \\
N×C & 4 & 144.53 & 0.22 & $29.59^{* *}$ & 2.25 & 0.72 & $0.058^{*}$ & 0.003 & 0.302 & $0.008^{*}$ \\
Error & 16 & 10.147 & 0.92 & 2.74 & 1.11 & 0.44 & 0.015 & 0.001 & 0.105 & 0.002 \\
\hline
\end{tabular}

d.f.: Means degree of freedom; *,*: Significant at $(p=0.05),(p=0.01)$ level of probability, respectively

\begin{tabular}{lccccccc}
\hline \multicolumn{7}{l}{ Table 2: Effect of nitrogen rate on growth and yield attributing characters of fenugreek } \\
\hline $\begin{array}{l}\text { Nitrogen rate } \\
\left(\mathrm{kg} \mathrm{ha}^{-1}\right)\end{array}$ & $\begin{array}{c}\text { Plant height } \\
(\mathrm{cm})\end{array}$ & $\begin{array}{c}\text { No. of pods } \\
\text { plant }\end{array}$ & $\begin{array}{c}\text { No. of seeds } \\
\text { pod }^{-1}\end{array}$ & $\begin{array}{c}\text { Test weight } \\
(\mathrm{g})\end{array}$ & $\begin{array}{c}\text { Seed yield } \\
\left(\mathrm{mt} \mathrm{ha}^{-1}\right)\end{array}$ & $\begin{array}{c}\text { Green leaf } \\
\text { yield }\left(\mathrm{mt} \mathrm{ha}^{-1}\right)\end{array}$ & $\begin{array}{c}\text { Biological yield } \\
\left(\mathrm{mt} \mathrm{ha}^{-1}\right)\end{array}$ \\
40 & 87.10 & 44.89 & 10.44 & 9.19 & 1.15 & 0.33 & 3.58 \\
60 & 91.89 & 48.08 & 11.12 & 9.20 & 1.20 & 0.36 & 4.24 \\
SEm \pm & 109.69 & 51.31 & 12.08 & 10.02 & 1.38 & 0.38 & 4.28 \\
LSD $(p=0.05)$ & 1.06 & 0.55 & 0.35 & 0.22 & 0.04 & 0.01 & 0.12 \\
\hline
\end{tabular}

LSD: Least statistical difference

et al., 2013) which recorded highest for the nitrogen @ 60 kg $\mathrm{ha}^{-1}$ and this nitrogen also gave rise to maximum seed yield. Biological yield was found at par for the nitrogen @ $60 \mathrm{~kg} \mathrm{ha}^{-1}$ and $40 \mathrm{~kg} \mathrm{ha}^{-1}$. These findings indicate that higher doses of nitrogen are required for seed production than for biomass production. The results are in confirmatory to findings of Datta et al. (2005) that green leaf yield and seed yield increases with increase in nitrogen level.

Analysis of variance showed that all growth and yield parameters were affected by cutting stage except for biological yield (Table 1). The tallest plants and most branches plant ${ }^{-1}$ were for plants that were not cut (Table 3 ). Decrease in plant height with higher branches was observed with the effects of cutting which curbs the vertical growth of plant resulting in translocation of photosynthates to leaf axils thus, encouraging auxillary branches. The results are in agreement with Krishnaveni et al. (2014). Increases in number of pods plant $^{-1}$, number of seeds pod ${ }^{-1}$ and test weight was when plants were cut at 45 DAS or 60 DAS (Table 3). Increased green leaf and seed yield were obtained when cutting was at 60 DAS 
(Table 3) which resulted in the maximum harvest index. The findings are supported by Rana et al. (2015). Sowmya et al. (2017) also reported that delaying in pinching of leaves found to be superior in respect of green leaf and seed yield including harvest index.
Analysis of variance showed that interaction between nitrogen rate and cutting management had significant effect on no. of pods plant ${ }^{-1}$, seed yield and harvest index (Table $1)$. The interaction results showed that the most pods plant ${ }^{-1}$ (60.36) and seed yield (1.75 mt ha ${ }^{-1}$ ) was for the nitrogen @

\begin{tabular}{|c|c|c|c|c|c|c|c|c|}
\hline Cutting & $\begin{array}{l}\text { Plant height } \\
(\mathrm{cm})\end{array}$ & $\begin{array}{l}\text { No. of } \\
\text { branches } \\
\text { plant }^{-1}\end{array}$ & $\begin{array}{l}\text { No. of pods } \\
\text { plant }^{-1}\end{array}$ & $\begin{array}{c}\text { No. of } \\
\text { seeds pod }^{-1}\end{array}$ & $\begin{array}{c}\text { Test } \\
\text { weight } \\
\text { (g) }\end{array}$ & $\begin{array}{c}\text { Seed yield } \\
\left(\mathrm{mt} \mathrm{ha}{ }^{-1}\right)\end{array}$ & $\begin{array}{c}\text { Green leaf } \\
\text { yield } \\
\left(\mathrm{mt} \mathrm{ha}^{-1}\right)\end{array}$ & $\begin{array}{c}\text { Harvest } \\
\text { index }\end{array}$ \\
\hline None & 110.85 & 8.38 & 38.11 & 11.07 & 8.91 & 1. 09 & 0.00 & 0.27 \\
\hline 45 DAS & 95.83 & 7.08 & 51.71 & 10.39 & 9.49 & 1. 21 & 0.49 & 0.31 \\
\hline 60 DAS & 82.00 & 6.46 & 54.45 & 12.19 & 10.00 & 1.43 & 0.57 & 0.36 \\
\hline SEm \pm & 1.06 & 0.32 & 0.55 & 0.35 & 0.22 & 0.04 & 0.01 & 0.01 \\
\hline $\operatorname{LSD}(p=0.05)$ & 3.21 & 0.97 & 1.67 & 1.06 & 0.67 & 0.13 & 0.04 & 0.04 \\
\hline
\end{tabular}

DAS: means days after sowing; LSD: Least statistical difference

$60 \mathrm{~kg} \mathrm{ha}^{-1}+$ cutting at 60 DAS (Table 4). The maximum harvest index (0.44) was for this treatment might be due to a higher proportion of seed yield than biological yield. This treatment also produced additional return from green leaves yield which might be due to less accumulation of dry matter in the herbs of plant. Our findings are closely related with the results of Gill et al. (2001) and Dahiya et al. (2009).

Table 4: Interaction effect between nitrogen and cutting for number of pods, seed yield and harvest index of fenugreek

\begin{tabular}{|c|c|c|c|}
\hline Nitrogen×cutting & $\begin{array}{l}\text { No. of pods } \\
\text { plant }^{-1}\end{array}$ & $\begin{array}{l}\text { Seed yield } \\
\left(\mathrm{mt} \mathrm{ha}^{-1}\right)\end{array}$ & $\begin{array}{l}\text { Harvest } \\
\text { index }\end{array}$ \\
\hline $20 \mathrm{~kg} \mathrm{ha}^{-1} \times$ none cutting & 37.98 & 1.06 & 0.30 \\
\hline $\begin{array}{l}20 \mathrm{~kg} \mathrm{ha}^{-1} \times \text { cutting at } \\
45 \text { DAS }\end{array}$ & 46.18 & 1.12 & 0.32 \\
\hline $\begin{array}{l}20 \mathrm{~kg} \mathrm{ha}^{-1} \times \text { cutting at } \\
60 \mathrm{DAS}\end{array}$ & 50.49 & 1.26 & 0.34 \\
\hline $40 \mathrm{~kg} \mathrm{ha}^{-1} \times$ none cutting & 38.01 & 1.07 & 0.26 \\
\hline $\begin{array}{l}40 \mathrm{~kg} \mathrm{ha}^{-1} \times \text { cutting at } \\
45 \text { DAS }\end{array}$ & 53.71 & 1.24 & 0.31 \\
\hline $\begin{array}{l}40 \mathrm{~kg} \mathrm{ha}^{-1} \times \text { cutting at } \\
60 \text { DAS }\end{array}$ & 52.51 & 1.28 & 0.29 \\
\hline $60 \mathrm{~kg} \mathrm{ha}^{-1} \times$ none cutting & 38.34 & 1.14 & 0.24 \\
\hline $\begin{array}{l}60 \mathrm{~kg} \mathrm{ha}^{-1} \times \text { cutting at } \\
45 \text { DAS }\end{array}$ & 55.24 & 1.25 & 0.30 \\
\hline $\begin{array}{l}60 \mathrm{~kg} \mathrm{ha}^{-1} \times \text { cutting at } \\
60 \text { DAS }\end{array}$ & 60.36 & 1.75 & 0.44 \\
\hline SEm \pm & 0.96 & 0.07 & 0.02 \\
\hline $\operatorname{LSD}(p=0.05)$ & 2.90 & 0.22 & 0.07 \\
\hline
\end{tabular}

\section{Conclusion}

Farmers usually practice cutting only if the crop is grown for vegetable purpose. However, the results of this work indicate that there may be an additional benefit of leaf yield with increased seed yield if fenugreek fertilized with nitrogen at a level of $60 \mathrm{~kg} \mathrm{ha}^{-1}$ in addition to cutting be practiced at 60 days after sowing.

\section{References}

Ahmed, M., Oladiaran, J.A., 2012. Effect of stem cutting and variety on shoot development and seed yield of jute mallow (Corchorus olitorious L.). Experimental Agriculture and Horticulture 12(3), 21-29.

Dahiya, M.S., Nandal, J.K., Phor, S.K., 2009. Effect of nitrogen and green leaf cutting on seed yield of fenugreek. Haryana Journal of Horticultural Sciences 38(1/2), 110-111.

Datta, S.K., Alam, R., 2005. Effect of different levels of nitrogen and leaf cutting on growth, leaf and seed yield of fenugreek (Trigonella foenum-graecum). Indian Journal of Agricultural Sciences 75(9), 580-581.

Donald, C.M., 1962. In search of yield. Journal of Australia Institute of Agriculture Sciences 28, 172-178.

Gill, B.S., Randhawa, G.S., Saini, S.S., 2001. Effect of sowing dates and herb-cutting management on growth and yield of fenugreek (Trigonella foenum-graecum). Indian Journal of Agronomy 46(2), 364-367.

Gomez, K.A., Gomez, A.A., 1984. Statistical procedures for agricultural research, $2^{\text {nd }}$ ed. John Wiley Sons, New York.

Korus, A.A., Lisiewska, Z., 2009. Effect of cultivar and harvest date of kale (Brassica oleracea L. var. acephala). Polish Journal of Environmental Studies 18(2), 235-241.

Krishnaveni, V., Padmalatha, T., Padma, S.S., Prasad, A.L.N., 2014. Effect of pinching and plant growth regulators on growth and flowering in fenugreek (Trigonella foenum- 
graecum L.). Plant Archives 14(2), 901-907.

Lakshmi, J., Gowda, R., Parashivamurthy, Narayanaswamy, S., Shivanandan, V.N., 2015. Influence of pre-flowering pinching and Maleic hydrazide spray on plant growth, seed yield and quality attributes in fenugreek. Legume Research 38(3), 353-357.

Parthasarathy, V.A., Kandinnan, K., Srinivasan, V., 2008. "Fenugreek". Organic Spices. New India Publishing Agencies, 694.

Rana, S.C., Pandita, V.K., Sirohi, S., 2015. Influence of spacing and number of leaf cuttings on seed yield in fenugreek. Legume Research 38(6), 858-860.

Singh, K.P., Nair, B., Jain, P.K., Sengupta, S.K., 2013. Correlation studies in fenugreek (Trigonella foenum-graecum L.). African Journal of Agricultural Research 8(38), 47734779.

Sowmya, P.T., Naruka, I.S., Shaktawat, R.P.S., Kushwah, S.S., 2017. Effect of sowing dates and stage of pinching on growth, yield and quality of fenugreek (Trigonella foenum-graecum L.). International Journal of Bioresource and Stress Management 8(1), 091-095.

Syeda, B.B., Muhammad, I.B., Shahabuddin, M., 2008. Antioxidant activity from the extract of fenugreek seeds. Pakistan Journal of Analytical and Environmental Chemistry 9(2), 78-83.

Tehelan, S.K., Thakral, K.K., 2008. Effect of different levels of nitrogen and leaf cutting on leaf and seed yield of coriander (Coriandrum sativum L.). Journal of Spices and Aromatic Crops 17(2), 180-182.

Tunctruk, P., Colen, A.E., Tunctrunk, M., 2011. The effect of nitrogen and sulphur fertilizers on the yield and quality of fenugreek (Trigonella foenum-graecum L.). Turkish Journal of Field Crops 16(10), 69-75.

Vidyashankar, G.K., 2014. Fenugreek: An analysis from trade and commerce perspective. American Journal of Social Issues and Humanities (Fenugreek Special Issue) 4, 162-170. 